\title{
A NEW SPECIES OF PLECTOCARPON (ROCCELLACEAE, LICHENISED ASCOMYCETES) FROM INDIA
}

\author{
Y. Joshi ${ }^{1,2}$, S. Upadhyay ${ }^{2,3}$, K. Chandra ${ }^{2}$, K. Bisht ${ }^{2,3}$ and A. Falswal ${ }^{2}$ \\ ${ }^{1}$ Forest Ecology and Biodiversity Conservation, Forest Botany, Kerala Forest Research Institute, \\ Peechi-680653, Kerala, India; E-mail: dryogeshcalo@gmail.com \\ ${ }^{2}$ Lichenological Laboratory, Department of Botany, S. S. J. Campus, Kumaun University, Almora \\ - 263601, Uttarakhand, India \\ ${ }^{3}$ Biodiversity Conservation and Management Theme, G. B. Pant Institute of Himalayan \\ Environment and Sustainable Development, Kosi-Katarmal, Almora-263643, Uttarakhand, \\ India
}

(Received 20 May, 2016; Accepted 15 June, 2016)

\begin{abstract}
A new gall-inducing and lirellate lichenicolous fungus, Plectocarpon diedertzianum Y. Joshi, Upadhyay et Chandra, is described from Kumaun Himalayan regions of India colonising thallus of various parmelioid lichens (Flavoparmelia caperata, Myelochroa aurulenta, Parmotrema crinitum, P. melanothrix, $P$. reticulatum, Punctelia subrudecta). The new species is characterised by black, epruinose rounded to lirellate ascomata with a carbonised surface and a \pm thalline pseudomargin, as well as a carbonised, sterile stromatic tissue, 4-spored asci and 3-septate hyaline ascospores.
\end{abstract}

Key words: Arthoniales, lichens, lichenicolous fungi, parmelioid, taxonomy

\section{INTRODUCTION}

The widespread ascomycete's lichenicolous genus Plectocarpon Fée (Roccellaceae, Arthoniales) is mainly characterised by multilocular stromata, usually inducing gall-like structures on the host thalli, Opegrapha-type asci, usually 3-septate, rarely 1 or (4-)5-6(-7)-septate ascospores, which sometimes become brown at maturity. The genus has been well worked out across the globe (Aptroot et al. 1997, Cáceres et al. 2001, Diederich and Etayo 1994, Ertz and Diederich 2007, Ertz and van den Boom 2012, Ertz et al. 2003, 2005, Etayo 2007, Hafellner et al. 2002, Hawksworth and Galloway 1984, Kukwa et al. 2012, Lawrey and Diederich 2015, Santesson 1993, 1994, Scholz 1998, Wedin and Hafellner 1998) and is so far represented by 38 species (including P. syncesioides Cáceres et Lücking, a lichenised fungus) across the world.

Since the monograph of Ertz et al. (2005) six new species have been described in the genus Plectocarpon: five lichenicolous species on hosts belonging to Dirinaria (Ertz and van den Boom 2012), Hypogymnia (Zhurbenko et al. 2008), cf. Siphula (Etayo and Sancho 2008), Stereocaulon (Kukwa et al. 2012) 
and Usnea (Etayo 2007), and one lichenised species, P. syncesioides Cáceres et Lücking (Cáceres 2007).

Generally most of the species of this genus parasitises members of Lobariaceae and Nephromataceae (Peltigerales; Kukwa et al. 2012), but members of Cladoniaceae, Ramalinaceae, Parmeliaceae, Physciaceae and Sphaerophoraceae (Lecanorales; Diederich and Etayo 1994, Ertz et al. 2005, Etayo 2007, Etayo and Sancho 2008, Ertz and van den Boom 2012, Zhurbenko et al. 2008) are also parasitised by species of this genus.

Till now only six species of this genus have been reported on members of Parmeliaceae: Plectocarpon encausticum (Nyl.) R. Sant. (on Brodoa intestiniformis), P. hypogymniae (on Hypogymnia bitteri), P. melanohaleae Christnach, Ertz et Diederich (on Melanohalea ushuaiensis), P. usneae Diederich et Etayo (on Usnea exasperata), P. usneaustralis Etayo (on Usnea sp.) and an undescribed species on Usnea (Ertz et al. 2005, Zhurbenko et al. 2008). In the present manuscript, we are describing a new species of Plectocarpon from India, apparently parasitising various species of parmelioid lichens, thus raising the number of Plectocarpon species to 39 and number of infected Parmeliaceae members to 7.

\section{MATERIALS AND METHODS}

The samples were collected from Binsar Wildlife Sanctuary, Dhaula Devi, Futsil and Tapogiri forests situated in Almora, Nainital and Pithoragarh districts of Kumaun Himalaya, Uttarakhand. The methods of study are same as those of Ertz et al. (2005). Morphological features of specimens were analysed by using a stereozoom dissecting microscope (Olympus SZ2-ILST), while anatomy was studied on hand-cut sections mounted in water, $10 \%$ $\mathrm{KOH}$ solution (K) and Lugol's solution without (I) or with (K/I) $\mathrm{KOH}$ pretreatment under Olympus CX21iLEDFS1 microscope. Spores were measured in water using Olympus CX21iLEDFS1 microscope. Measurements are given as follows: (minimum-) mean-standard deviation - mean - mean+standard deviation (-maximum) followed by the number of measurements $(n)$. For other characters, the minimum and the maximum values are given.

\section{RESULTS AND DISCUSSION}

Plectocarpon diedertzianum Y. Joshi, Upadhyay et Chandra, spec. nova (Fig. 1A-G)

MycoBank no.: MB 817746

Similar to Plectocarpon opegraphoideum, but differs in having 4-spored asci, narrower ascospores ((2.5-)3.0-3.5 $\mu \mathrm{m})$ and different host. 
Type: India, Uttarakhand, Pithoragarh district, Gangolihat, Futsil Sacred forest, on Myelochroa aurulenta and Parmotrema reticulatum colonising Quercus leucotrichophora. Coll.: Upadhyay, S., Bisht, K. and Joshi, P. (LF-06/2015), 3 May 2015. Holotype: LWG; isotype: KU.

Ascomata "apothecia", gall-inducing, developing apically on upper surface of the thallus, dispersed to more often confluent, strongly convex, rounded to angular, prominent, blackish-brown, surface matt, cracked and epruinose, surface from the very beginning coarsely wrinkled, later with distinct labyrinth form or lirellate ornamentation (Fig. 1A-C), 42.5-62.5(-100) $\mu \mathrm{m}$ in diameter, thalline margin \pm restricted to the basal part. Stroma multilocular (Fig. 1D), globose, single to confluent, surrounded by orange-brown to black (in thick sections) sterile prosoplectenchymatous stromatic tissue, $\mathrm{K}+$ olive-brownish, $\mathrm{N}+$ reddish brown, without immersed crystals (pigment: Atra-brown, see Ertz et al. 2005, Meyer and Printzen 2000); (50-)66.81-75.5084.18(-100) × (62.5-)122.42-134-145.57(-212.5) $\mu \mathrm{m}(\mathrm{n}=50)$, with carbonised surface (Fig. 1D-E). Hymenium not or slightly exposed, hyaline, I+ blue, K/ I+ blue, entirely filling the loculi, 100-130 $\mu \mathrm{m}$ high, usually divided in several loculi separated by sterile stromatic tissue (Fig. 1D); hymenial gel K/I+ blue. Epihymenium brownish, I+ blue, K/I+ blue. Paraphyses abundant, richly branched and anastomosing, septate, 1.5-3.0 $\mu \mathrm{m}$ thick, apical cells slightly swollen. Asci Opegrapha-type, clavate, (2-)4-spored, $(65-) 70-90(-100) \times 15-20$ $\mu \mathrm{m}$, distinct apical K/I+ blue ring, wall K/I- (Fig. 1F). Ascospores overlapping in 2-3 rows in an ascus, hyaline, fusiform to narrowly skittle-shaped, smooth, (1-)3-septate, slightly constricted at the septa, all cells are more or less equal in length, $(10-) 10.88-14.72-18.55(-20) \times(1.5-) 2.50-3.33-5.0(-5.15) \mu \mathrm{m}(\mathrm{n}=50)$, perispore distinct (especially in young ascospores), hyaline, up to $1 \mu \mathrm{m}$ thick (better seen in K), brown pigmentation not observed (Fig. 1F-G). Pycnidia not observed.

Distribution and habitat: The species is reported from temperate regions of Kumaun Himalaya, Uttarakhand, where it is growing in Quercus-dominated Binsar Wildlife Sanctuary, Dhaula Devi, Futsil and Tapogiri forests on thallus of Flavoparmelia caperata, Myelochroa aurulenta, Parmotrema crinitum, P. melanothrix, P. reticulatum and Punctelia subrudecta.

Remarks: The new species is mainly characterised by black coloured lirellate ascomata having carbonised stromatic tissue and narrow ascospores ((2.5-)3.22-3.42-4.07(-5.0)). Plectocarpon opegraphoideum Christnach, Ertz, Diederich et Wedin and P. aff. pseudosticta Fée, two closely related species differ from the new taxon in having I+ blue quickly turning red hymenium, (4-)6-spored asci, having broader ascospores ((4-)4.3-5.1(-5.5) and 5.1-5.9 $\mu \mathrm{m}$, respectively) and different hosts (Pseudocyphellaria homoeophylla and $P$. multifida for Plectocarpon opegraphoideum, while Pseudocyphellaria intricata and P. thouarsii for Plectocarpon aff. pseudosticta). 
In having rounded and warty ascomata, the new taxon resembles Plectocarpon encausticum (Nyl.) R. Sant., P. latisporum Ertz, Diederich et Wedin and P. bunodophori Wedin, Ertz et Diederich, but these species differ from the new taxon in having different hymenium I-test, number of spores in asci and ascospore size (see Ertz et al. 2005).

The six previously known lichenicolous species of this genus (Plectocarpon encausticum, P. hypogymniae, P. melanohaleae, P. usneae, P. usneaustralis and
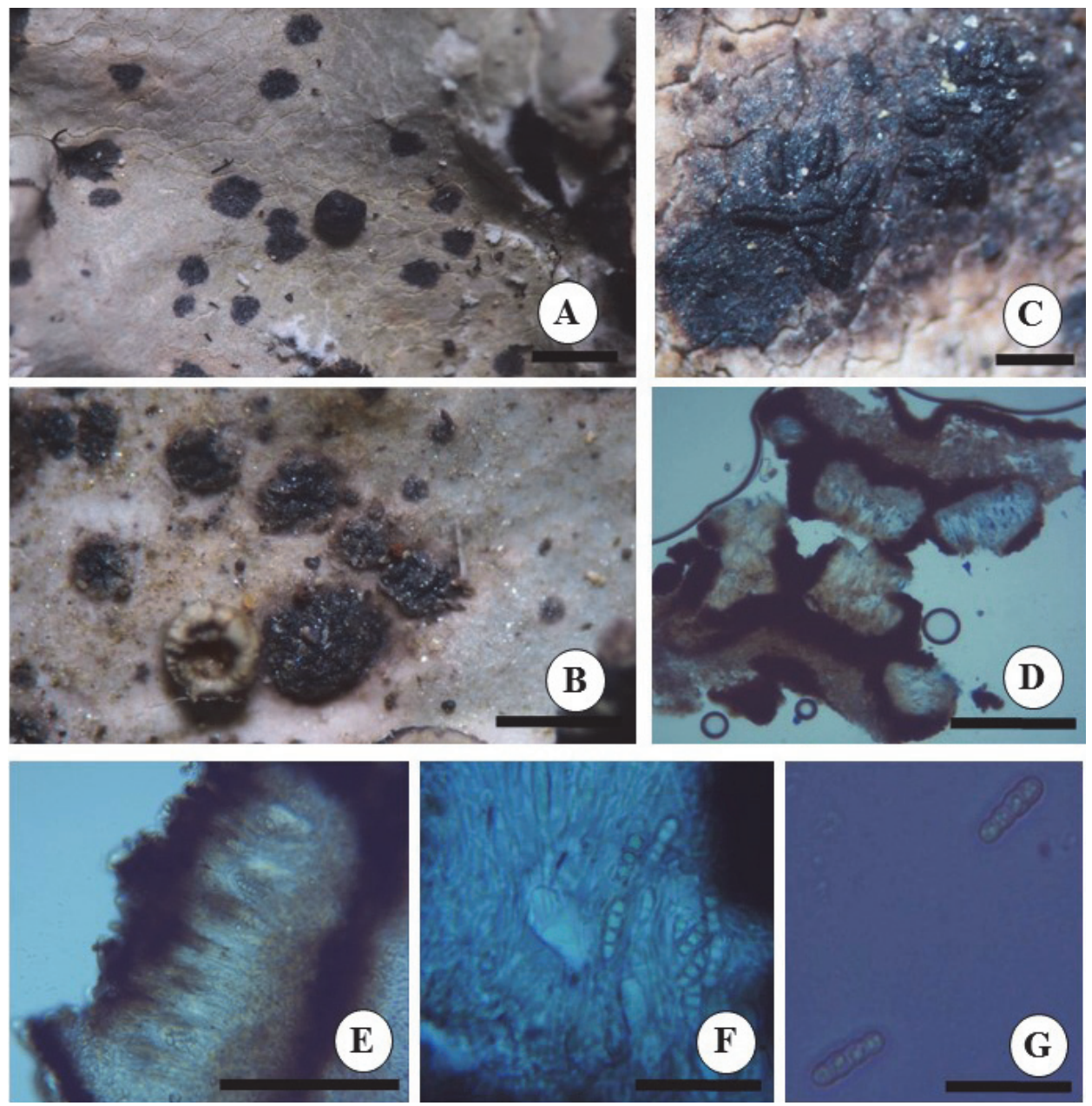

Fig. 1. Plectocarpon diedertzianum holotype. $\mathrm{A}=$ Thallus with gall (scale bar $=1 \mathrm{~mm}$ ), $\mathrm{B}=\mathrm{en}-$ larged view of gall (scale bar $=1 \mathrm{~mm}), \mathrm{C}=$ lirellate apothecia (scale bar $=1 \mathrm{~mm}$ ), D = transversal section of stroma (scale bar $=50 \mu \mathrm{m}$ ), $\mathrm{E}=$ enlarged view, vertical section through apothecium (scale bar $=100 \mu \mathrm{m}$ ), $\mathrm{F}=$ spores in ascus (scale bar $=10 \mu \mathrm{m}$ ), $\mathrm{G}=$ spores (scale bar $=10 \mu \mathrm{m}$ ) 


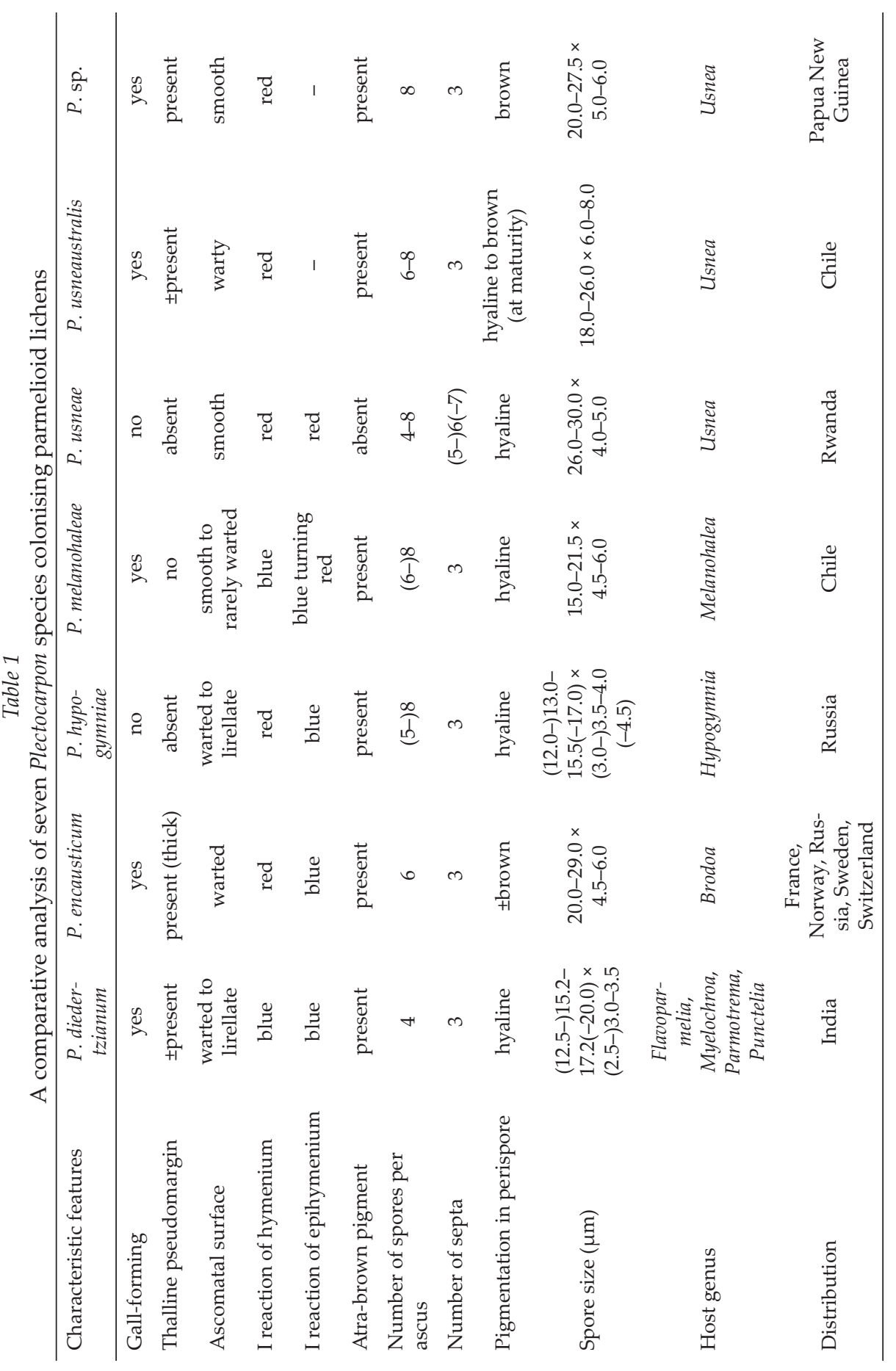


Plectocarpon sp.) colonising members of Parmeliaceae, differ from the new taxon in several characters (Table 1).

Etymology: The species is named in honour of Drs Paul Diederich and Damien Ertz for their monographic work on Plectocarpon and describing several new species belonging to this genus. Four initials of both Diederich and Ertz were combined to form diedertzianum.

Representative specimens examined: India, Uttarakhand, Almora District, Banari Devi Sacred forest, on Myelochroa aurulenta colonising Quercus leucotrichophora, Joshi, Y. and party (LF-01/2013), 8 December 2013 (KU); on way to Danya, Dhaula Devi forest, on Parmotrema reticulatum colonising rock, 16 May 2015, Shashi Upadhyay, Krishna Chandra and Kapil Bisht, LF-24/2015 (KU); ibid., on Parmotrema reticulatum colonising rock, Shashi Upadhyay, Krishna Chandra and Kapil Bisht, LF-33/2015 (KU); ibid., on P. crinitum colonising Q. leucotrichophora, Upadhyay, S., Chandra, K. and Bisht, K. (LF-32/2015) (KU); ibid., on P. reticulatum colonising Q. leucotrichophora, Upadhyay, S., Chandra, K. and Bisht, K. (LF-30/2015) (KU); ibid., on M. aurulenta colonising Q. leucotrichophora, Upadhyay, S., Chandra, K. and Bisht, K. (LF-31/2015) (KU); Binsar Wild life Sanctuary, on P. melanothrix colonising Q. leucotrichophora, Joshi, Y. (LF-36/2015), 9 August 2015 (KU); Nainital District, Ramgarh, Talla Ramgarh, Tapogiri forest, on Punctelia rudecta and Flavoparmelia caperata colonising Q. leucotrichophora, Bisht, A. and Joshi, P. (LF-38/2015), 30 September 2015 (KU); Pithoragarh District, Gangolihat, Chamunda Devi forest, on F. caperata, Bisht, K., Bisht, P. and Bankoti, D. (LF-06/2014), 4 April 2014 (KU); Badabe Village, Thal Ke Dhar forest, on M. aurulenta colonising Q. leucotrichophora, Upadhyay, S. (LF-01/2015), 16 January 2015 (KU); Gangolihat, Jadapani forest, on M. aurulenta and Parmotrema reticulatum colonising Q. leucotrichophora, Chandra, K. and party (LF-04/2015), 2 May 2015 (KU); ibid., on P. crinitum colonising Q. leucotrichophora, Chandra, K. and party (LF-05/2015) (KU); Futsil Sacred forest, near Himalayan Gramya Vikas Samiti, on M. aurulenta colonising Q. leucotrichophora, Upadhyay, S., Bisht, K. and Joshi, P. (LF-21/2015), 3 May 2015 (KU); ibid., on Punctelia subrudecta colonising Q. leucotrichophora, Upadhyay, S., Bisht, K. and Joshi, P. (LF-19/2015) (KU); ibid., on M. aurulenta, Upadhyay, S., Bisht, K. and Joshi, P. (LF-11/2015) (KU); ibid., on P. subrudecta, Upadhyay, S., Bisht, K. and Joshi, P. (LF-18/2015) (KU); ibid., on P. reticulatum colonising Q. leucotrichophora, Chandra, K. and Kumar, N. (LF-08/2015, LF-20/2015) (KU); ibid., on P. crinitum colonising Q. leucotrichophora, Chandra, K. and Kumar, N. (LF12/2015, LF-13/2015, LF-14/2015, LF-15/2015) (KU); ibid., on P. tinctorum colonising Q. leucotrichophora, Chandra, K. and Kumar, N. (LF-10/2015) (KU); ibid., on M. aurulenta colonising Q. leucotrichophora, Chandra, K. and Kumar, N. (LF-09/2015) (KU); ibid., on M. aurulenta colonising Pyrus pashia, Chandra, K. and Kumar, N. (LF-17/2015) (KU); Guptadi forest, on M. aurulenta and Flavoparmelia caperata colonising Q. leucotrichophora, Chandra, K. and party (LF-07/2015), 3 May 2015 (KU).

Acknowledgements - One of the authors (YJ) would like to thank Scientific and Engineering Research Board (SB/FT/LS-313/2012) and University Grants Commission (41-488/2012(SR) \& 20-1/2012(BSR)/20-2(16)/2012(BSR) for financial assistance, and to Dr Paul Diederich for his expert opinion and providing valuable literature. Thanks are extended to Director, Kerala Forest Research Institute and Head, Department of Botany, S. S. J. Campus, Almora for providing laboratory facilities. 


\section{REFERENCES}

Aptroot, A., Diederich, P., Sérusiaux, E. and Sipman, H. J. M. (1997): Lichens and lichenicolous fungi from New Guinea. - Biblioth. Lichenol. 64: 1-220.

Cáceres, M. E. S. (2007): Corticolous crustose and microfoliose lichens of northeastern Brazil. - Libri Botanici 22: 1-168.

Cáceres, M. E. S., Diederich, P., Lücking, R. and Sérusiaux, E. (2001): Chiodecton epiphyllum is a lichenicolous fungus on Coenogonium flavicans and belongs in the genus Plectocarpon (Arthoniales: Roccellaceae). - Lichenologist 33: 503-506. http://dx.doi. org/10.1006/lich.2001.0356

Diederich, P. and Etayo, J. (1994): Taxonomic notes on the genus Plectocarpon (lichenicolous Ascomycotina). - Nordic J. Bot. 14: 589-600. http://dx.doi.org/10.1111/j.1756-1051.1994. tb00654.x

Ertz, D. and Diederich, P. (2007): Plectocarpon. - In: Nash III, T. H., Gries, C. and Bungartz, F. (eds): Lichen flora of the Greater Sonoran Desert Region. Vol. III. Lichens Unlimited, Arizona State University, Tempe, pp. 402-403.

Ertz, D. and van den Boom, P. P. G. (2012): Plectocarpon dirinariae (Arthoniales), a new lichenicolous species from Cape Verde. - Lichenologist 44: 591-593. http://dx.doi. org/10.1017/s0024282912000345

Ertz, D., Christnach, C., Wedin, M. and Diederich, P. (2005): A world monograph of the genus Plectocarpon (Roccellaceae, Arthoniales). - Biblioth. Lichenol. 91: 1-155.

Ertz, D., Zhurbenko, M., Diederich, P. and Miadłikowska, J. (2003): A new species of Plectocarpon (lichenicolous Roccellaceae, Ascomycota) on Peltigera. - Bryologist 106: 465-467. http://dx.doi.org/10.1639/15

Etayo, J. (2007): Two new lichenicolous fungi: an Opegrapha and a Plectocarpon species (Ascomycota: Roccellaceae) from Chile. - Lichenologist 39: 543-547. http://dx.doi. org/10.1017/s0024282907007128

Etayo, J. and Sancho, L. G. (2008): Hongos liquenícolas del Sur de Sudamérica, especialmente de Isla Navarino (Chile). - Biblioth. Lichenol. 98: 1-302.

Hafellner, J., Triebel, D., Ryan, B. D. and Nash III, T. H. (2002): On lichenicolous fungi from North America. II. - Mycotaxon 84: 293-329.

Hawksworth, D. L. and Galloway, D. J. (1984): The identity of Plectocarpon Fée, and its implications for Lichenomyces pseudocyphellaria and the typification of Sticta delisea. - Lichenologist 16: 85-89. http://dx.doi.org/10.1017/s002428298400013x

Kukwa, M., Etayo, J. and Flakus, A. (2012): Plectocarpon stereocaulicola (Roccellaceae, Ascomycota), a new lichenicolous fungus from Bolivia. - Lichenologist 44: 479-482. http://dx.doi.org/10.1017/s0024282912000151

Lawrey, J. and Diederich, P. (2015): Lichenicolous fungi - worldwide checklist, including isolated cultures and sequences available. http://www.lichenicolous.net [accessed 20/05/2016]

Meyer, B. and Printzen, C. (2000): Proposal for a standardized nomenclature and characterization of insoluble lichen pigments. - Lichenologist 32: 571-583. http://dx.doi. org/10.1006/lich.2000.0294

Santesson, R. (1993): The lichens and lichenicolous fungi of Sweden and Norway. - SBT-förlaget, Lund.

Santesson, R. (1994): Fungi Lichenicoli Exsiccati, Fasc. 7 \& 8 (Nos 151-200). - Thunbergia 6: 1-18. 
Scholz, P. (1998): Phacopsis doerfeltii, sp. nov., and two other interesting lichenicolous fungi from Canada. - Sauteria 9: 37-42.

Wedin, M. and Hafellner, J. (1998): Lichenicolous species of Arthonia on Lobariaceae with notes on excluded taxa. - Lichenologist 30: 59-91. http://dx.doi.org/10.1017/ s0024282998000061

Zhurbenko, M. P., Diederich, P. and Otnyukova, T. (2008): Plectocarpon hypogymniae (Roccellaceae), a new lichenicolous species from Siberia. - Bryologist 111: 328-330. http://dx.doi.org/10.1639/0007-2745(2008)111[328:phranl]2.0.co;2 